\title{
Sustainability Impact Assessment - An Overview with a Holistic and Transdisciplinary Perspective towards Agricultural Research
}

\author{
Savio Barros de Mendonca \\ University of Montpellier and IRD, France \& Embrapa, Brazil \\ Anne-Elisabeth Laques \\ Institut de Recherche pour le Développement - IRD, France
}

Received: June 3, 2017 Accepted: June 27, 2017

doi:10.5296/emsd.v6i2.11333 URL: https://doi.org/10.5296/emsd.v6i2.11333

\begin{abstract}
It is important to insert agricultural research in this paper by considering it as a strategic area for providing knowledge and a technological base for agricultural production, considering that this sector generates outcomes with respective impacts to rural zones, supply-chain, economy, society and environment, representing a key piece for reaching United Nations objectives of sustainable development to each country and to the planet. Aiming to analyze how agricultural research organizations (as for instance: INRA and CIRAD, from France and EMBRAPA, from Brazil) have driving sustainability impact assessment methodologies and their interaction with transdisciplinary and holistic principles, using as a base innovation concepts. This paper will display an overview on concepts and approaches about sustainability impact assessment, but looking from a transversal perspective, passing by an historical description on impact assessment and on concepts related to sustainable development and sustainability. We will search for unedited models of sustainability impact systems by converging holism, transdisciplinarity and sustainability. There are several methodologies but few demonstrate an integrated view with a transversal perspective. It is also imperceptible any concrete governance-managerial system for sustainability impact assessment, considering every stage of the process, from a strategic to an operational level, including, analyzing environment, economy and society dimensions as one unique perspective. Such as a complex and multidimensional sector of economy, agricultural research requires profiled sustainability impact assessment with an innovative and dynamic approach.
\end{abstract}


Keywords: Sustainability, Impact, Assessment, Holistic, Transdisciplinary, Transversal

\section{Introduction}

\section{From a general contextualization toward expectation and goals}

This paper aims to identify conceptual approaches, methodologies, advances and challenges as well as to discuss and make inferences on sustainability impacts assessment; accomplishing analysis with an integrated, holistic and transversality perspective, analyzing some types of existing methodologies, systems and indicating the best applicability for each one. Concepts and methodological approaches will be analyzed toward research and innovation institutions, especially those used in the agricultural sector. In this scope, for evaluating sustainability impacts of any research organization it will be necessary to assess impacts of their products, technologies, processes and services. This effort will demand reviewing some conceptual bases related to impact assessment and the dimensions related to the sustainability principle, followed by reviewing the real concept of holism and transversality of knowledge. All the collected information will permit confronting the theoretical ideal world and the complex and conflicted real world. By retrieving approaches we can identify that environment and social-economic issues, historically, was main vectors for the first extensive discussion on impact assessment systems. Finally we will make a reflection on future expectations of innovative impact appraisal processes.

To address sustainability on the planet it is necessary to think about sustainable development policies in the nations and the respective compliance between them and endorsed international concepts, agreements, laws and protocols on sustainable development driven by United Nations (UN) and its derivative programs and initiatives, and especially considering the level of sustainable behaviors internalized by public organizations, private organizations, nongovernmental organizations and citizens. All of them are the representatives of the nations, and human life depends of their actions in the real world.

Despite efforts from several national governments and organizations around the world that incorporate concepts and guide-lines on sustainable development in their policies and strategic plans, the distance between what would be reasonable stage to the hard reality is visible, especially if we consider the level of people that have internalized principles toward sustainable behaviors. After 20 years, since Rio-92, it was clear that a huge gap existed between idealized sustainable development and the real results reached by nations: the feeling of frustration showed for great part of global leaderships boosted the UN representative members to identify different actions to drive Rio+20 Conference, its processes and reports (UN, 2012).

In this paper we are going to restrict our analysis to the organizations in general, and especially those used in the agricultural research sector. The organizations (public, private or nongovernmental) are the entities through which policies, plans, programs, projects, processes and activities are accomplished: as a final result, organizations generate products and services and their impacts. Thereby, to verify if the world will walk towards the sustainability direction, one of the most fundamental mechanisms is to evaluate the impact of 
the organization's policies, programs, projects, products, services and activities.

There is a program theory that analyzes how a project will, or has, generated impact. This program theory comprises the tracking of results or of the impact pathway. This process begins with the project input; passes by the output stage, followed by a chain of intermediate outcomes that are followed by extensive and often longer-term outcomes. The GTZ, Germany cooperation organization (currently GIZ), adopted this program theory evaluation to guide their projects impact assessment. This approach has a two-phase assessment, the first one is used to guide a self-monitoring and evaluation, and the second phase is an independent ex post impact assessment (Douthwaite, 2003) "that would normally be carried out several years after the project has been finished" (Douthwaite, 2003).

The pathway approached by Douthwaite creates the theoretical base for assessing ex-ante (as planning phase) and ex-post (as outcome phase). Based in these approaches it is recommendable that evaluation considers the ex-ante and ex-post analysis, the first one as a sense of prevention and the second one as a mechanism for feedback and correction of the project's planning and management.

This paper methodology will be based on a literature review and practical cases of some organizations. A historical synthesis on the theme will be made and will present a condensed approach about concepts of: Sustainability Assessment, Sustainability Impact Assessment, Integrated Assessment, Holism and Transdisciplinarity and adjacent concepts to these issues, as well as description on some organizations experiences from the perspective of case studies.

\section{Contextualization: Overview on History, Approaches, Problems and Concepts}

\subsection{Brief Historical Approach and Problems}

The Limits to Growth published by the Club of Rome had relevant impact in the world when in the early 1970s demonstrated how fragile the planet was due unreasonable use of resources. The Brundtland Report evidenced that greedy production systems provoked degradation and depletion on natural resources and negative impact on the planet. This report coined the bases for sustainable development definitions endorsed by United Nations in the Rio Earth Summit by Agenda 21 (Bond and Morrison-Saunders, 2011).

The first important reaction of negative environmental impacts occurred in 1969, in the United States, when the National Environmental Policy Act (NEPA) was created, as resulted from pressure of the popular movements in that country related to environmental questions. In the scope of NEPA initiatives, beginning in the early 1970s emerged the legal base, the methodology and the procedures of Environmental Impact Assessment (EIA) and next, the Social Impact Assessment (SIA) which also included economic impacts addressed to large-scale projects. These instruments merged as part of social sciences and as components of the policy-making process (Freudenburg, 1986).

At present there are several models and systems for impact evaluation such as: social, environmental, technological, economic and fiscal (Becker, 2001), as well as health assessment (Wernham, 2011). In the last 15 years companies have been publishing social and 
environmental reports as tools of accountability which means transparency for stakeholders, also as an instrument of social and environmental responsibility, e.g. Sustainability Report based on GRI - Global Report Initiative (GRI, 2017).

\subsection{Concepts and Approaches}

\subsubsection{Economic Assessment (EA)}

The economic assessment, that forms part of the social impact assessment, aims towards examining all aspects that might contribute to the gain or loss of individual, community, regional or national resources. An economic impact analysis examines the effects of a policy, project, or event on the local economy (MasterQResearch, 2010). Economic impacts assessment of an organization can be analyzed by verifying direct impact, indirect impact and induced impact. The first one is the economic benefit that resulted from all activities and products generated by the organization; the second one is directed to the economic benefits and employment generated to the connected supply chain of the products and services produced by the organization; and the third one represents the benefits that arise when employees of the organization and its supply chain spend their earnings, locally or anywhere (Oxford Economics, 2015). The catalytic economic impact is a relatively new concept that shows long term effects on other different productive chains or organizations or other sectors of economy (Oxford Economics, 2013). Alston (1995) consolidates his approach and econometric theories applied to the agricultural sector by focusing on economic impact analysis of agricultural technologies and research projects and their effects to the agricultural producers and the consumers.

\subsubsection{Environment Assessment}

The International Assessment Impact Association - IAIA defines impact assessment as a "process of identifying the future consequences of a current or proposed action" (2006). Based on the first concept for environmental impact assessment defined by NEPA, added by several global discussions in the UN conventions and international meetings, UNEP defined EIA as an instrument for identifying environmental, social and economic impacts of specific projects which must be elaborated before their decision for design and implementation (UNEP, 2004). The Convention on Biological Diversity - CBD (2006) defines EIA as a process of assessing possible environmental impacts of a proposed project or development initiative, considering socio-economic, cultural and human-health impacts, by taking into account that all the dimensions are interconnected, identifying both positive and negative effects. If EIA are implemented to assess the effects of individual or operational projects, a wider evaluation can be applied Strategic Environmental Assessment which is suitable to appraise policies and programs (CBD, 2006). According to Sadler and Dalal-Clayton (1999) "Strategic Environment Assessment (SEA) is conceptualizing as the formalized, systematic and comprehensive process of identifying and evaluating the environmental consequences of proposed policies, plans or programs to ensure that they are fully included and appropriately addressed at the earliest possible stage of decision-making on a par with economic and social considerations. In order to improve the quality of policy processes towards consistent sustainable development strategies, the European Commission implemented an impact 
assessment (IA) which was elaborated to be a process that could provide data and information for policy decision makers, demonstrating advantages and disadvantages of a possible policy and its effects (De Smedt, 2010). According to FAO (2012), EIA is a tool for decision-making process, important tool for identifying potential environmental risks for new projects. It is an important support for prevention, mitigation, management and monitoring measures. FAO adopts an approach to measure ex-ante impacts for operational initiatives, but it is also used for policy dialogue with countries before begin projects (FAO, 2012).

To help organizations identify, manage, monitor and control the environmental impacts related to their activities it is fundamental to construct an environmental management system, especially using an integrated approach with a holistic perspective (ISO, 2015). Toward this vision, ISO set the voluntary norm ISO 14001 designed to orientate how organizations can implement environmental management systems, step by step. As a consequence of that, ISO created the Life Cycle Sustainability Assessment (LCSA) ISO 14040 norm, as a voluntary standardization, aiming to be adopted ex-ante of implementing projects and activities. It is also important to consider ISO 26000 - Social Responsibility Guidance Standard as technical reference for enlarging analysis by integrating social responsibility with environmental responsibility, generating an integrated impact assessment (UNEP, 2011).

\subsubsection{Social Assessment}

In accordance with the Becker concept (Becker and Vanclay, 2003) Social Impact Assessment (SIA) is "the process of identifying the future consequences of a current or proposed actions which are related to individuals, organizations and social macro-systems". To Vanclay, social impact is: "the process of analyzing and managing the intended and unintended consequences of planned interventions on people so as to bring about a more sustainable and equitable biophysical and human environment".

In view of SIA being considered as a continuous process, not limited by technical practices, it is complicated to set limits (Becker and Vanclay, 2003). The current tendency has been to aggregate the economic with social assessment as part of impact studies. Then, we can consider socio-economic impact assessment (SEIA) as just one approach. It is also important to consider that the traditional environment impact assessment analysis has being to include the socio-economic studies into the EIA approaches. In this case, SEIA intends to identify and evaluate the potential socio-economic and cultural impacts of a proposed development projects on the lives and circumstances of people, their families and their communities. "If such potential impacts are significant and adverse, SEIA can assist the developer, and other parties to the EIA process, find ways to reduce, remove or prevent these impacts from happening" (The Review Board, 2007).

It has been usual to insert health impact to the social impact - it was apprehensible some decades ago, when the first steps of impact assessment processes were rehearsed. Nowadays the health theme wins space in the concern of people, organizations and countries towards the search for quality of life. Thereby, health analysis tends to be amplified into social impact assessment. "Health impact assessment is a structured process that brings together scientific data, public health expertise and principles, and stakeholder input to identify the potential 
health effects of a proposed policy, program, project, or plan and to craft health-based recommendations" (Wernham, 2011). In accordance with the Gothenburg consensus paper (ERCHP, 1999) Health Impact Assessment - HIA is defined as a set of procedures, methods and tools that must analyze and foresee risks for the health of a population and other possible consequences within the population.

\subsubsection{Sustainability Assessment}

Brundtland report that was main base for conceptualizing sustainable development, recognizing that sustainability derives from this concept root: "Humanity has the ability to make development sustainable to ensure that it meets the needs of the present without compromising the ability of future generations to meet their own needs"(UN, 1987). In 1992 and from this base-concept, the United Nations made critical considerations about decision-making process of nations and organizations which separated in their analysis, policies, projects and actions the social, from economic from environmental dimensions. Based on that argument, UN inserted at Agenda 21, the definition of sustainable development as a process that have to consider socio-economic and environmental issues as one fully, inseparable and integrated components, which will require broader range of public participation (UN, 1992). In fact, there are gaps among United Nations sustainability concept and many organizations and projects in the practical world. Reality demonstrates that policies, projects and actions of many institutions and companies still separating these dimensions.

This item, search to recover the importance of sustainability original concept and to demonstrate the necessity of enlarging from environmental, social or economic dimension to an inseparable and integrated view among these three components, especially when referring on assessment processes. The objective of sustainability assessment is to guarantee that strategic or operational actions become a positive contribution to sustainable development (Verheem, 2002). Sustainability assessment is a tool created to support policy-makers and decision-makers to minimize or avoid negative impacts or optimize positive impacts, aiming to make society more sustainable today and in the future (Pope et al, 2004). The broadest discussions related to environment assessment recommends inserting social and economic dimensions into the environmental scope, reflecting the three pillars of sustainability (environmental, social and economic) and resulting in form of integrated assessment, also called the Three Bottom-Line - TBL (Pope et al, 2004). Integrated assessment is also defined as "an interdisciplinary process of synthesizing, interpreting and communicating knowledge from diverse scientific disciplines in order to provide relevant information to policy-makers on a specific decision problem" (EEA, 2001).

Several methodologies based to integrated assessment models - IAMs approach, have been developed since the 1980's. Despite its use in other areas, this approach has been essentially focused on climate change issues. Due to its flexibility and adaptability feature many models have been developed and adapted based on IAM. With an interdisciplinary outlook, this approach considered complex analysis interfacing social-economic and environmental dimensions by its subcomponents, especially related to energy and long term effects resulted from simulations of future scenarios (Yang, 2016). As a framework based on the scope of the 
European Union, a process of IAM has been proposed as a means for reaching better results in the ex-ante assessment, as well as improving the management of complex systems (Harris, 2002). IAM represents a mix of disciplinary models, using quantitative methods and producing several sustainability indicators (Ewert et al, 2015). With an interdisciplinary vision and considering three dimensions of sustainability, Sustainability Impact Assessment SIA is a methodology addressed by OECD focused in social, economic and environmental dimensions, ex-ante from policies and programs on a strategic level, analyzing potential impacts of policies before their implementation, as well as, offering alternatives for decision-makers by alerting the possible risks and opportunities (OECD, 2010). Participatory Integrated Assessment is an integrated approach that, necessarily uses, stakeholders participatory method, as for instance in analyzing agricultural systems of production (Delmottea et al, 2013).

Sustainability Reports based on GRI is a periodical report published by private and public organizations as a way of demonstrating to consumers, clients, stakeholders and to the society at large, its sustainable responsibility level and performance based on their annual activities. With this report organizations have to show positive and negative results and impacts from their processes and products. Besides economic, social and environmental dimensions, recent reports have also been including financial and non-financial performance and have an accountability report. Partners of company and financiers feel safer to continue investing in the company and public organizations can demonstrate transparency and establish more trust for a better relationship with the government (GRI, 2017).

\subsubsection{Holism, Disciplinarity, Multidisciplinarity, Interdisciplinarity and Transdisciplinarity}

Holism was firstly defined in 1926 by the South-African Jan Smuts. He said: "the whole is more than the sum of its parts. The entire universe was based on an innate tendency for stable wholes to form from parts" (Gatherer, 2010). Against reductionist approaches, the holistic approach requires a comprehension of complex systems based on an ensemble of hierarchies that go from the macro level to the nano level, from the universe to subatomic particles. "For a cell biologist, holism might mean thinking about the whole liver". Depending on the context it might mean the "whole person, the whole community, the whole of society, or the whole planet". Then the scale will define your context to apply the holism concept (Freeman, Joshua, 2005).

To reach the transdisciplinarity concept it is important to begin by understand disciplinarity, multidisciplinarity and interdisciplinarity. Disciplinarity can be understood as a category to scientific knowledge organization, divided according to typical specialization. Despite each specialization it is set into a wide scientific grouping, due to its own border, each discipline tends to reach its autonomy by its own theories, techniques and languages. If we just assembly several disciplines we have multidisciplinarity. Yet, this approach focused to the (mono) disciplinarity, especially from the 1950s, does not refuse the classical science and also does not compete with it. Even so, a knowledge revolution begun by Physics has quarreled with ideas of order, separability, reduction and classical logic, transforming and changing the prevailing scientific paradigm (Morin, 1990). Then, as a second knowledge 
revolution systemic sciences came to re-arrange disciplines around interaction complexes or of one object that can be called a system (Morin \& Le Moigne, 2003). The world has been evolving towards a new dynamic of life that requires not only new discussions on multidisciplinarity, but new attitudes toward transdisciplinarity. Recently cross-cut vision and integrative behavior have been required for business management as well as for academy, science \& innovation (Roquete et al, 2012).

According to Piaget (1972) the approach on interdisciplinarity, represents a cooperative process that results from real reciprocities among people (scientists, specialists, technicians or professionals) and mutual enrichment, however, transdisciplinary research is a new trend for knowledge construction (Cohen and Lloyd, 2014). In the information or knowledge society, there is a need for transdisciplinary research, i.e., research that deals with complex life-world problems. Transdisciplinary projects aim to come up with practice-oriented solutions that serve what is perceived to be the common good. In order to achieve this, they transcend disciplinary boundaries and include the perspectives of public agencies, the business community and civil society in the research process (Hadorn and Pohl, 2007). "Transdisciplinary projects are those in which researchers from different fields not only work closely together on a common problem over an extended period but also create shared conceptual models of the problem that integrates and transcends each of their separate disciplinary perspectives" (Mitrany \& Stokols, 2005). "Transdisciplinarity is a principle for organizing processes of mutual learning and problem solving between science and society. Thus, transdisciplinarity may contribute to sustainable development” (Scholz, 2000).

\subsubsection{Impact Assessment - by an Integrated Perspective}

This article's core is impact assessment, by a sustainability perspective. Then, it is essential to define "assessment" and "impact". Assessment implicates in quantitative and qualitative analysis, making estimates or valuation and can be focused on four objectives: 1) evaluate processes; 2) evaluation of generated products/services; 3 ) evaluation of generated outcomes; 4) evaluation of generated impacts (to the environment, economic and society - farmers, industries, services, local, regional and national governments, stakeholders and consumers). Impacts have two dimensions to be considered: a) the scale (local, intra-regional, national and international) and b) dimension time (short, mid and long term of effect, as well as, passing time or continuous effect). Impact is defined as the positive and negative, primary and secondary long-term effects produced by a development intervention, directly or indirectly, intended or unintended. These effects can be economic, socio-cultural, institutional, environmental, technological or of other types. Organizations have to be capable to use all results of impact studies to deliver accountability to stakeholders (Bantilan et al, 2014).

To understand impacts as broad or long-term effects and about its pathways stages require some basic definitions. The stage outputs means the products, services or facilities that result from planned and accomplished solutions. Outcomes are impacts resulted from solutions (products, services and facilities). Before making product and service impacts appraisal (ex-post) it is essential to assess those processes before implementation (ex-ante) as a preventive measure. This is necessary because, after they have been generated, products and 
services will affect the environment and people who are direct or indirect user's of those solutions, and their effects will reflect on stakeholders, and may also affect government policies, all of which can generate reflexes for the short term or even for many years (NCVO, 2017).

Since the end of the 2000s, pressured by innovation chains and induced by industries and production systems, as well as, due to government rules towards good use of public resources, normally imposed by financial resources restrictions, many countries have been impelled to develop systems of impact assessment (Ruegg \& Feller 2003). Research Impact Assessment RIA, experienced especially by agricultural sector research institutions, search, mainly, to evaluate the impact of research to the economy and society, from an ex-post analysis (Joly, P. et al., 2016). RIA has been interesting for organizations that work on science and innovation, research ecosystems and about studies for management effective of research funding, and especially as an approach adopted by public organizations especially to measure economic and social impacts of its research, as also a form of accountability for governments, partners and society (ISRIA, 2017). Especially focused to study and evaluate policies generated by European Union, the Impact Assessment Institute was created in 2015, and, according to its vision, 'impact assessment' covered all processes of a policy, from the conception stage, passing by the legislation phase, to its implementation stage and consequent impacts, until the construction of a new policy, requiring monitoring and respectively ex-ante and ex-post appraisal (IAI, 2017).

When we analyze the UN Sustainable Development Goals, we can identify how agriculture represents a strong sector for reaching these goals. From the 17 goals established by the UN, goals $2,3,6,8,12,13$ and 15 have direct relation to the agricultural activity and their impacts to the environment, economy and society. This reality leads us to converge our impact assessment analysis to this segment, with a special focus to research organizations and taking into account their impact evaluation systems for solutions (technologies, products, processes and services) for producers, supply-chains and society (UN, 2015). CGIAR is a global research organization that congregates 15 agricultural research centers around the world (CGIAR, 2017). CGIAR Research Impact Assessment evaluates ex-post impacts of their developed technologies when used in the field and creating links from generated data and information to support ex ante assessment and orients plans, as a way to improve research management and to be transparent for their financiers (Merrey, 2015). In France, there are two important agricultural research institutions: INRA (L'Institut national de la recherche agronomique, in English, the National Institute for Agricultural Research) and CIRAD (Centre de coopération internationale en recherche agronomique pour le développement, in English, Center for International Cooperation of Agronomic Research for Development, whose mission is to contribute to the agricultural innovation and research development in countries of the south). For some years, both institutions have been developing systems for evaluating impacts of their agricultural research, primarily focused on the socio-economic impacts and more recently they have included the environmental dimension. INRA believes that research contributes not only to generate scientific knowledge, however they have to be directed towards agriculture, supply-chain, food, and environment by means of innovating in 
production. Based on the RIA approach, this institution implemented a document called ASIRPA, which represented in a methodology for analyzing effects from their research, with strong emphasis on agronomic and socio-economic impact to producers and supply-chain (Colinet et al, 2014).

Named Impress (IMPact of RESearch in the South), CIRAD has developed a system for evaluating impacts of its technologies production. This organization understands that to assess impact it is necessary to grasp recent innovation concepts and how the innovation process demands a collective complex interaction among actors. CIRAD (Barret et al, 2015) says that, the main role of a research institution is to develop research, but when it goes facing real world, sometimes the cause of impact results from different activities that are not necessarily derivative from the research, due to current speed of information, and dynamism of the processes of creativity and innovation. Interaction among different actors generates complex combinations for identifying technology demands and risks of unpredictable, diffuse and complex impacts. Therefore, to analyze impacts it is necessary to connect policies strategic plans - programs - projects - processes - activities and products/services and understand that for construct all this process demands an open innovation perspective (technological innovation and/or management innovation) and an active inter-relationship with co-creation assembling actors along the whole process. While research contributes, sometimes strongly, to impact, it does not mean that some impacts can result from lack of interaction with research. To analyze impacts we may use two pathways: ex-ante (will analyze relation among programs, projects, out-put / outcome supported by an hypothetic path and projecting expected results and impacts) and ex-post (comparatively analyzing what was planned and what was reached in terms of the outcome and its consequences on development) (Barret et al, 2015).

Since the 1970's Brazilian Agricultural Research Corporation - Embrapa has been developing systems for impact assessment. At the beginning focused on economic impact analysis, especially due to the financial restrictions for the public sector, by considering that this organization is essentially supported by governmental resources and impact analysis would be a way to demonstrate to the federal government its institutional and economic effectiveness. After the 2000's impact analysis became multidimentional by including social and environmental dimensions as part of this process, generating a Social Balance, based on integrated impact assessment and mainly supported by a methodology called Ambitec-Agro (Rodrigues et al, 2010). Recently, as a result from a request of the Brazilian Supreme Audit Institution, Embrapa has inserted Social Balance as part of its financial and accountability report, generating an integrated report which reflects the social, environmental and economic impacts resulted from its technologies and the services produced, as well as, demonstrating its transparency concerning the government's and society's expectations on the application of its resources (Embrapa, 2017).

\section{Methodology}

The discussion method will adopt confrontation between the practical world of organizations versus ideal world of concepts, as well as, the possible limitations on the appraisal process 
under a holistic and transversal insight. At the discussion stage qualitative analysis will be adopted. Thus, this paper will adopt the following stages:

a) Literature review - a bibliographical review was made, with scientific papers and books, aimed at carrying out a historical rescue of themes such as sustainable development, sustainability, evaluation, impact, holism, transdisciplinarity, evaluation of economic, social and environmental impacts and through an integrated perspective of sustainability assessment.

b) Insertion of current scenarios on the issue - we carried out a survey of information related to the application of sustainability impact assessment approaches, with a special focus on research organizations, including a correlation analysis with concepts and innovation processes.

c) Synthetic case study of some organizations - case studies represent a methodological way to research current reality, as well as to confront theory versus its applicability, including the identification of gaps between these two points. In this direction, we have made a synthetic case study, aiming to confront the concepts and approach on impact assessment versus the practical world, in this case, applied to three agricultural research institutions: INRA, CIRAD (both from France) and Embrapa (from Brazil). Despite local environmental, social and economic different realities, the objective of this comparative analysis was to identify methodological aspects.

d) Inferences and conclusions - along the process of discussion and conclusions, some comparative analyzes and inferences about the concepts and reality researched were carried out, indicating the need for future complementary research related to the work carried out, including deepening some issues that, due to the methodological and structuring aspects of this article, were not possible further study.

\section{Discussion}

After concept and approach sequences, as well as, a historical overview concerning impact assessment and sustainability, now we are going to confront them with holism and transdisciplinarity approaches and taking an overview on how some agricultural research organizations have being studying and working with impact assessment and their solutions (technologies, products, processes and services).

To create a planetary sustainable society it is necessary that organizations and people of countries adopt sustainable attitudes. Evaluation impact systems will operate as an azimuth and thermometer indicating the grade and correct direction towards sustainability. If it is apparently irrelevant to measure the individual impacts of the global population, in spite of its complexity, it seems more important to assess collective, organizational, policy, plan, project and service impacts, although small cumulative impacts can generate large and lasting effects to the social, economic and ecological environment (Eccleston, 2011). Private and public organizations are responsible for implementing policies, plans, projects and activities and generate products and services. All of them provoke some sort of impact on the environment, economy and society, on the local, national or global space scale, with effects through the 
supply-chain and by diffused ways, during a variable time scale. Organizations have to adopt a creative and proactive competence as a way to identify stakeholder's diverse needs and demands (Asif et al, 2011), as well as, ways of managing internal conflicts and impacts from their production to the society and environmental (Chowdhury, 2013), it means to concentrate efforts to create an internal sustainability culture for facilitating the generation of sustainable impacts from their processes, products or services.

This analysis drives us to question the ways used for assessing sustainability impacts related to organizations and their policies, plans, programs, projects, processes, activities and respectively products and the services generated. If we lead this discussion to public research institutions and directed agricultural research organizations, current concern toward sustainability are still fragile and we can view potentially disconnected impact evaluation systems by a great part of these organizations. Among other issues, deforestation, loss of biodiversity, water scarcity, pollution, climate change, poverty, hungry, social inequity, economic crisis, all these questions have interconnection with the agricultural sector and have been hardly discussed around the world, and several global policies, agreements and programs have been driven by multilateral organisms and some national, multinational or local organizations, but there are clear gaps between policies and concrete results. Lately interest in sustainability research has grown, "however, the mainstream scientific methodologies are often poorly equipped to deal with complex sustainability problems" (Popa et al, 2015).

Transition Management (TM) has been a recent interdisciplinary approach in attempt to answer new ways for governance into complex and multiple scenarios, immersed in uninterrupted change and uncertainties demanding a sustainable society. These approaches (experienced by the Dutch government) search to adopt flexible and adaptable structures for working into an ambience with fragmented policies that requires resilient behavior, stimulating knowledge and technological changes, innovation and incremental improvements, especially paying attention to relevant actors. TM creates adequate conditions for legal compliance and for navigating with effectiveness in this dynamic social, economic and ecological environment (Loorbach \& Rotmans, 2010).

Therefore, TM is a holistic approach that operates under a transversal vision and asks for systemic models that can view from policy/strategy stage, passing by tactical, operational and monitoring /evaluation stages, and understanding that one stage cannot be effective without another. Sustainability Transition is a field of research intrinsically linked to the transition management approach. In fact, it denotes a new field for thinking outside of traditional approaches and intends to exit from traditional social-technical vision to a more sustainable mode of production and consumption. Besides traditional disciplines as ecology, biology, agronomy, sociology and economy, impact assessments have to enlarge for other areas participation in their argumentative and integrative process. Sustainability transition approach includes: economic geography, philosophy of science, science of education, science of health, science of policy, management studies, information technology and several fields normally not considered in impact assessment processes. Empirical insights are as important as a scientific outlook (Markard et al, 2012). 


\section{MInstitute Machink $_{\text {Inthe }}$}

Transdisciplinary approaches require attention on three aspects: cognitive, structural, and processual. "Effective cognitive leadership provides a vision that links and motivates transdisciplinary researchers to step beyond their disciplinary lens, relax old assumptions, and search for creative frame-breaking solutions. Effective structural leadership adds value by creating needed bridges among unconnected parties. Effective processual leadership encourages trust and turns potentially destructive conflict into constructive interactions" (Gray, 2008).

In effect, we will not find perfection in just one approach and challenge is to use a magnifying glass to filter each good contribution to structure a more complete, in-depth and holistic methodology. It is a reasonable multidisciplinarity; but, interdisciplinarity represents an advance over multidisciplinarity, because in human relationships processes, only, transdisciplinarity is a wider approach, with the exercise of empathy, including social and all stakeholders participation for policy and project construction, no restricted to scientists and policy makers. Hence, we need to respect all areas of scientific knowledge, the traditional knowledge and valuable savvy tied to professional and life experiences. It is necessary to adopt a mind opening attitude for new learning and experiences and thus, permit the construction of a hybrid approach, multidiverse and responsive to the height of complexity that the issue requires. Transdisciplinarity demands an open mind and attitude to auscultate the others, including citizens, consumers, all kind of producers, representative members of society, that is basic for construct sustainable societies (Popa et al, 2015). Scientists who are working with sustainability issues recognize the urgency to migrate from restrictive multidisciplinary and interdisciplinary approaches towards transdisciplinary collaborations, which implicate to join scientific and extra-scientific expertise (Popa et al, 2015). Holism and transdisciplinarity are two transversal necessary components for reaching effectiveness on impact assessment analysis either ex-ante or ex-post.

Usually Economic Impact Assessment is adopted in private organizations relating aspects of marketing and investment feedbacks. In public organizations it has been used as part of an integrated assessment processes for ex-ante or ex-post stage. It has a strong microeconomic component when it refers to individual organizations or farm economic results. Or yet, can be used to show economic performance and accountability, also applicable to public organizations. In agricultural research organizations it has been used for evaluating impact from generated and adopted technologies, with consequent effects over supply-chain and reflexes to local or national income. Despite its operational application, its results are important for strategic analysis.

In general, Social Impact Assessment is aggregated to economic assessment; it has not being adopted alone and has been an important component on integrated assessment processes. This dimension approach is according to the type of project, namely, and can include aspects such as: health, nutrition, education, cultural, citizenship and others. SEI has been adopted in assessment processes which hold economic and social dimensions, without the environmental component. But, in fact, it is a way to display clearly that both dimensions have been joined in just one package during analysis processes, with expectations that balance between social and economic dimensions. HIA Normally is adopted in activities related to the health sector. 
It could include much more in every impact assessment processes, because human health is directly or indirectly influenced by all economic activities or development projects, or even by research projects, especially in agricultural activity, both at the production stage and in the food chain.

Historically EIA emphasizes environmental aspects by its analytical process, although it includes social and economic dimensions, with more or less stress to one or another. Undoubtedly a great part of real cases demonstrate environmental and social emphasis, as FAO EIA methodology, that is frequently adopted for agricultural projects, what is naturally expected due environmentalist origin of EIA, and considering that economy depends on a good social quality of life and both dimensions (economic and social) are inserted to ecological environment. SEA is applicable to policies, plans or programs with expectation of large impacts to environment and/or relevant social and economic effects, through short, mid or long terms. This approach has generally been applied by government organizations, but also by big companies. Really it could be adopted in much larger scale for any kind of organization as part of its strategic plan to orientate tactical and operational activities regarding environmental, social and economic impacts. By considering three dimensions of sustainability, Integrated Assessment - IA (TBL=Three Bottom-Line) approach has demonstrated a larger multivision than only environmental vision with an operational scale, it has normally been directed to the ex-ante stage of project that demonstrates clear impact risks to environment and society before implementing projects. SIA is an approach adopted by OECD, with detailed analysis of potential risks and opportunities according to an environmental, social and economic perspective. Even if it is restricted to a policy or strategic level, it effectively demonstrates its sustainability approach and efforts to be interdisciplinary, despite showing certain complexity or low practicality to be implemented.

IAM is adopted by many groups and institutions, as for instance: European Union and for provisioning of conceptual basis for Intergovernmental Panel on Climate Change- IPCC. This approach has been applied to evaluate risks and opportunities by environmental and socio-economic dimensions related to policies and plans. Considering many disciplines in its analysis process as: economic feasibility studies, anthropogenic greenhouse gas emissions and climate change, land use, biogeochemistry, hydrology, demography and health, this approach is an ongoing process and has been improved year-by-year as a result of contributions from various research groups that have been working with climate change. Despite its strategic nature, this approach sometimes has being applied at the operational level to evaluate ex-ante potential impacts of big projects (Yang, 2016); (OECD, 2010).

RIA is adopted by research organizations, and especially applied for public agricultural research organizations as a way to demonstrate economic balance resulting in financial investments in research and its positive return in terms of impact to GDP or local aggregated income, positive impacts to increase productivity and respectively economic gains for producers. This approach has been based on other derivative approaches that have included social and environmental dimensions. LCSA is a typical operational and detailed process for evaluating projects with high potentiality of environmental and social impacts. Specifically to assess project impacts, usually generating data that allows producing energy balance, carbon 
balance, viewing all stages or processes inherent to any project, product or service. This approach is very interesting for detailing SEI and/or EIA.

Focusing impact assessment discussion to agricultural research and innovation institutions, it is interesting to make a synthesized analysis of three public organizations that generate technological solutions for farmers and agricultural supply-chains: INRA, CIRAD and Embrapa.

Impact Analysis of the Public Agronomic Research - ASIRPA is highly based in RIA, this approach has been used in the National Agronomical Research Institute of France (INRA). It strongly has an agronomical and economic impact. It has been important to demonstrate effectiveness and effects to producers, supply-chain and GDP aiming economic sustainability for the research institution. It represents an important feedback for policies and strategies adjustments and to renew research priorities, but it would be interesting to set a clear pathway for reach efficacy on this feedback mechanism. Moreover, there is an interesting organizational unit in INRA, it is the Ethical Advisory Commitee for Agronomique Research. This Commitee makes analysis of public agronomic research impact and provides information to the ASIRPA system, as well as, feed the management upper about research internal profitability (INRA \& CIRAD, 2016). Finally, the approach needs to incorporate a stronger emphasis on the social and environmental dimensions and enfold stakeholders in the evaluation process.

Adopted by CIRAD, IMPact of RESearch in the South - IMPRESS is an approach similar to RIA, but with visible advances in incorporate social and environmental dimensions and also by hearing stakeholders. The conceptual approach is very interesting by creating expectation to link strategic and operational levels but, after case studies, results seems to reduce reflexes or feedbacks only to the operational level and it is not clear how it will connect results to the strategic level with effective impact to research priorities by using feedback mechanisms. The impact pathways is one crucial aspect emphasized by this approach, because it allows the identification of barriers and positive points with more facilities along the impact route, through its short, medium or long-term, as well as, with direct or indirect effects.

Brazilian Agricultural Research Corporation - EMBRAPA, each year, produces a Social Report that is a strategic report directed for stakeholders, Federal government court of accounts and for society in general, which adopts a method to aggregate and synthesize information in a institutional document by sampling of the three technological solutions generated by each one of its 41 research centers, and demonstrate effects of their technologies to supply-chain, farmers, local and national population direct or indirect affected for produced technologies, and also, reflexes for Gross Domestic Product (GDP) by rating of return estimation. The Ambitec-Agro (Integrated Impact Assessment) is an operational methodology that feed of data and information the Social Report elaboration by an aggregation process of information, aiming generates a strategic profile document (Rodrigues, 2015). Ambitec is a deep and detailed socio-environmental and economic assessment from each technology chosen, within sampling. This method plunges towards technologies impact analysis, with emphasis to environment component, although it includes the social and 
economic dimensions

Because the methodology has a wide spectrum in order to become adaptable to different types of agricultural technologies (for instance: prototypes, methods, processes, genetic material, animal semen, seeds, and other biotechnologies), it requires that local applicability respect the learning process of each involved research team, in accordance with each technology specificity, including complexities of ecological environment, characteristics of the farm and the production system adopted (Rodrigues, 2015).

The Ambitec-Agro system has been used as a tool to support the institutional management of agricultural research, as a document of accountability to the federal government (main agricultural research funder) and is a way of transparency for the society. In addition, it shows itself as an instrument for researchers to analyze the relevance of their scientific and technological contributions, and to define new priorities for research. The Ambitec allows evaluating several occurrences of negative or positive environmental indices that provoke impacts from the use of certain agricultural technology. For instance, plant and animal genetic improvement technologies effects are measured by basing on increased demand for inputs related to area extension, resulting in their potential negative (due to increase inputs use) or positive environmental impacts (when reduce agricultural areas due to intensification and productivity increased). Another identified aspect in this methodology are the parameters adopted for the agro-industrial and post-harvest technologies evaluation, according to demand levels for energy and inputs, which tend to generate negative environmental impacts in case of increasing or positive when reduction of these demands occurs . More, indicators were constructed based on criteria of technology impacts that can have environmental aspects as: quality of soil, quality of water, biodiversity, environmental recovery, atmosphere, use of inputs. Socio-economic aspects as: employment opportunities, income generation, quality and work conditions, food security, safety and health at work, productive ethic, institutional relation and other points (Rodrigues, 2015).

Approach indicates that some technologies can generate effects for many years, considering features of agricultural technologies and its biological, ecological, social and economic components. Recently, this approach regards aspects related to operational management while technologies are adopted and feed the Social Report, that is a strategic document. Despite its great advances if comparing with other methodologies, this approach could be improved if it could adopt the CIRAD experience for emphasizing impact pathways, as considered in IMPRESS methodology and regarding a wider approach of sustainable landscape indicators by a greater spatial and systemic view. Also, it could consider consumers through its analysis as a vital component of the supply-chain, that would become a more complex process, but indeed, challenging. In addition, Embrapa data and information resulted of its methodology could be an interesting input to Sustainability Report - GRI elaboration as part of a general assessment system (GRI, 2017).

Sustainability Report (SR) denotes a type of report that demonstrates to stakeholders the organization sustainability performance. Really ideal point would be to show negative and positive results found, but, generally SR, only demonstrates positive aspects. SR, according 
to GRI guide, suggests that organizations have to show the reality of the impact (positive and/or negative), which normally does not happen. SR based on GRI aims to demonstrate a transversal approach on impact sustainability and governance performance, well advanced in terms of multidisciplinarity and integrality report for the strategic level. Reports could be an opportunity for a strategic document aiming to promote adjustments on organizational policies and guidelines (as GRI suggests for reports construction), however, in practice several reports have been good merchandizing documents. According to the Global Reporting Initiative - GRI, sustainability reporting has being widely applied in private companies but, in the public sector it could be more adopted by institutions. It recommends this reporting standard as an important instrument to governments and market regulators in their policy for helping them to guarantee transparency and comparability among businesses, stakeholders and society (GRI, 2010). In fact, SR represents an important opportunity for public organizations, meantime, it would require that GRI guide adapts its language and structure for the public sector.

By analyzing impact assessment experiences, concepts and approaches and confronting it to a transversal, holistic and transdisciplinary perspective it is unavoidable to understand that would be necessary a governance and managerial system to see a complete process that begins at policy and planning stage, pass by tactical level and reach to operational which will generate products and services to be delivery to supply-chain and consumers, affecting microeconomic environments, with greater or lesser effects to macroeconomic, and impacting ecological environment more or less by different scales. To meet this expectation the Transition Management (Loorbach \& Rotmans, 2010) and Sustainability Transition (Markard et al, 2012) approaches express important contributions to be recovered for a more complete and integrated approach of sustainability impact assessment applicable for agricultural research institutions or any kind of organization.

Through a governance and managerial perspective, an impact system can be seen (see Figure 1 - General Impact System), where society's needs or demands plus environment requirements for its resilience can be identified. Both components will enable to capture data and to process information for planning and management orientation. Process will start with inputs, included policies/strategic orientations that will set bases for implementing projects and activities, next step are the outputs, then, comes the adoption of outputs, and finally outcomes with their respective impacts to society and environment. There is usually a time gap between direct and indirect impacts, with the possibility of diffuse effects on the environment, productive chains and society. This impact assessment system will supply information to innovation plan adjustments. Thus, with formulated policies/strategies/projects it will be possible to make a confrontation between ex-ante predicted impact (impact plan) with ex-post impacts (policies/projects and activities accomplished). The proposed system drives for a new wider approach which allows analyzing hypothetical steps, before begin a new policy or project until their performance. 


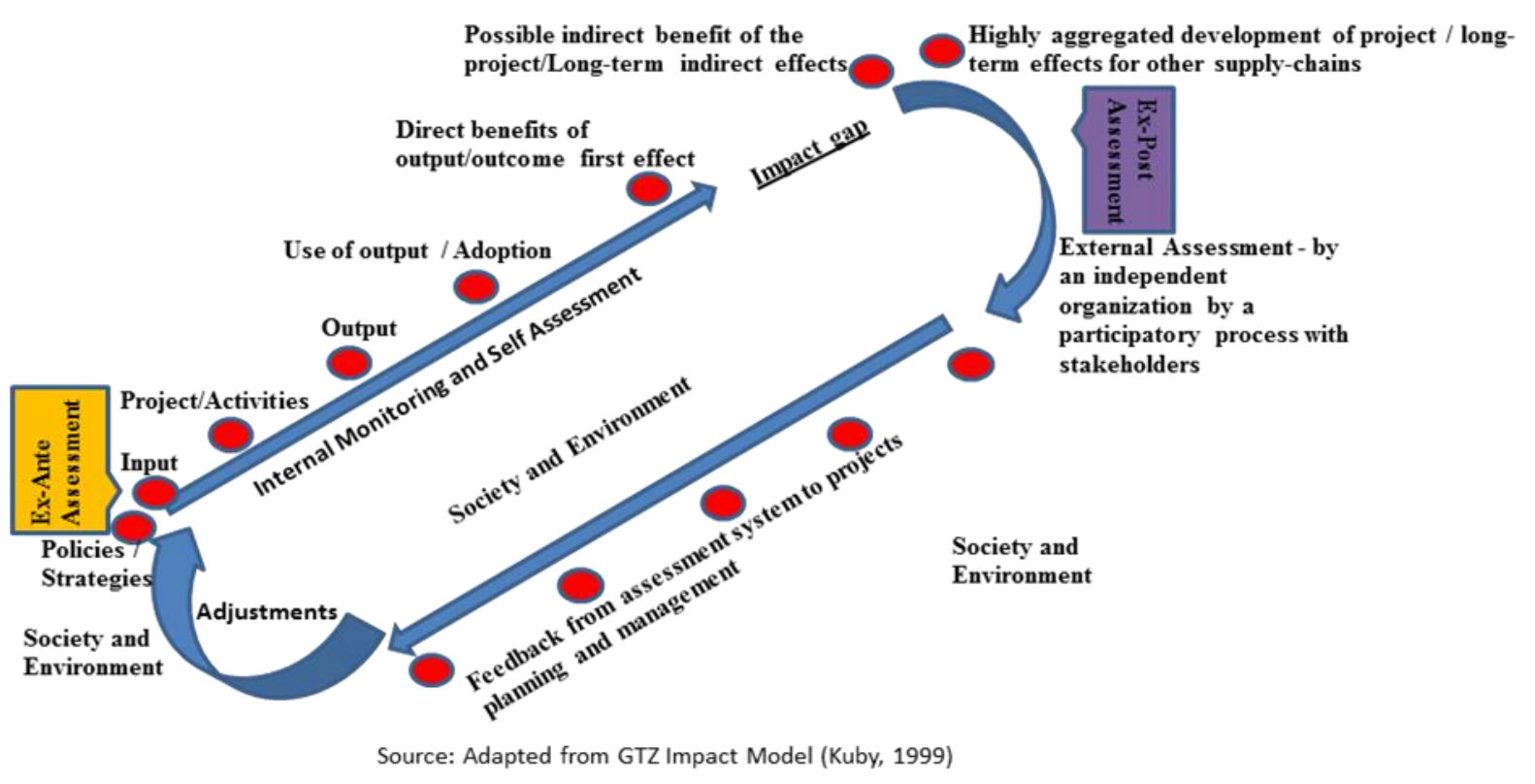

Figure 1. General impact system-by impact pathway approach

This system (above) resulted from the combination of Douthwaite (2003) and Kuby (1999) theories, which, also, afford to view impact pathways - interrelation between begining versus end of a project and their effects for short and long-term, as well as, showing integration internal and external ambience with self monitoring/evaluation and stakeholders by a participatory assessment process (Barret, 2015). It is recommended that, besides monitoring and ex-ante impact assessment by organization itself, the ex-post assessment can be done by independent organization (Douthwaite, 2003).

This analysis drives us to enlarge our thought towards innovation processes that is perfectly aligned with our goal of analyzing impacts of research organization. After all, the main role of a research organization is not to search for mere scientific curiosity but for innovation. Then, recovering innovation concepts we will make a brief contextualization. Into economic mainstream, the oldest theoretician of innovation, Schumpeter (1983), defined it: as new material and force combination that discontinuously arises, generating new goods which consumers are not used to; a new production method; the opening of a new market; conquest of a new supply of raw materials or semi-manufactured goods; breeding of a new productive organization. The latest version of the Oslo Manual, in 2005, set innovation categories: product innovation, process innovation, organizational innovation and marketing innovation as aspects of innovation approaches (Insee, 2016).

"Innovation is the process of making changes to something established by introducing something new" (O'Sullivan, 2009). An innovation can means something completely new or represents just a small increment, and it can be applied to products, processes or services. (O'Sullivan, 2009). It is basic that invention can reach to the market, however, it is not enough, it demands a feedback loop and deep relationship to society's needs, with following up its needs and desires, with unremitting dialogue between organization and society (Planing, 2017). Disruption innovation is another reading for innovation, which forecast that when a 
new actor enters to the market and frontally beats on competitors, offering better products or services, the oldest ones will try to innovate to defend their businesses (Christensen, 2015). Presently, open innovation has been the most modern trend for innovation approach, especially due our complex and dynamic information world which requires other organizational designs for innovation. Open innovation has been defined as "... the use of purposive inflows and outflows of knowledge to accelerate internal innovation, and expand the markets for external use of innovation, respectively" (Chesbrough et al., 2006). As we can see, innovation that represents a key role of research organizations is directly connected to necessary systems of impact assessment.

An organization, especially of the agricultural research sector, for improving and increasing its innovation process must assess the impact of all its solutions to farmers, supply-chain and society, as well as, have to evaluate impacts to the environment resulted from its technologies, products and services. In regard to the holistic and transdisciplinary perspective it would be important to consider the prism for innovation, videlicet, social innovations which means solutions (e.g.: technologies, products, services, processes) that meet social needs, with effective and positive impact to society, which promote social empowerment and can provide better quality of life (Pisano et al, 2015).

New practices often require new paradigms and desertion of ongoing practices that will happen only when decision-makers recognize a simple truth: "Sustainability = Innovation" (Nidumolu, 2009). "A major target of the SDG agenda is the eradication of hunger" (FAO et al, 2015), the, world increasingly demands food production, and well nourished people, now and to the future, requiring agricultural productivity by using sustainable solutions (FAO et al, 2015). Thereby, agricultural research organizations have an important role to generate increasingly sustainable technologies, products, processes and services that will be measured by managerial systems of impact assessment.

Nowadays trends indicate fragmented approaches towards integrated, holistic and transdisciplinary approach. Economic, social or environmental impact assessment is not more viable by dissociated analysis. An innovation discussion approaches the same trend, which means, sustainability innovation rather than separate social innovation, or economic or environmental innovation.

Based on previous conceptual stage and discussions an analytical synthesis demonstrated several approaches related to impact assessment, considered in this paper, as follows (Table 1). It is important to consider that this synthesis represents what is usually adopted in methodological terms and on field. 
Table 1. Impact Assessment Approaches - Analytical Synthesis

\begin{tabular}{|c|c|c|c|}
\hline Approach & $\begin{array}{l}\text { Application Scale } \\
\text { (Strategic / Tactical / } \\
\text { Operational) }\end{array}$ & $\begin{array}{l}\text { Timing of } \\
\text { Application } \\
\text { (Ex-Ante / } \\
\text { Ex-Post) }\end{array}$ & $\begin{array}{l}\text { Systematic Connection between } \\
\text { Innovation System and/or } \\
\text { Policies/Projects with Ex-Ante plus } \\
\text { Ex-Post Impact Assessment? }\end{array}$ \\
\hline Economic Impact - EI & $\begin{array}{l}\text { Operational } \\
\text { (projects) }\end{array}$ & Both & No \\
\hline Social Impact - SI & $\begin{array}{l}\text { Operational } \\
\text { (projects) }\end{array}$ & Ex-Ante & No \\
\hline $\begin{array}{l}\text { Social-Economic Impact } \\
\text { - SEI }\end{array}$ & $\begin{array}{l}\text { Operational } \\
\text { (projects) }\end{array}$ & Ex-Ante & No \\
\hline $\begin{array}{l}\text { Health Impact } \\
\text { Assessment - HIA }\end{array}$ & $\begin{array}{l}\text { Operational } \\
\text { (projects) }\end{array}$ & Ex-Ante & Partially \\
\hline $\begin{array}{l}\text { Environment Impact } \\
\text { Assessment - EIA }\end{array}$ & $\begin{array}{l}\text { Operational } \\
\text { (projects) }\end{array}$ & Ex-Ante & No \\
\hline $\begin{array}{l}\text { Strategic Environment } \\
\text { Impact - SEA }\end{array}$ & $\begin{array}{c}\text { Strategic (policies, plans, } \\
\text { programs) }\end{array}$ & Ex-Ante & No \\
\hline $\begin{array}{l}\text { Sustainable Impact } \\
\text { Assessment - SIA }\end{array}$ & $\begin{array}{c}\text { Strategic } \\
\text { (policies, plans, programs) }\end{array}$ & Ex-Ante & No \\
\hline $\begin{array}{l}\text { Integrated Assessment - } \\
\text { IA (TBL=Three } \\
\text { Bottom-Line) }\end{array}$ & $\begin{array}{l}\text { Operational } \\
\text { (projects) }\end{array}$ & Ex-Ante & No \\
\hline $\begin{array}{l}\text { Integrated Assessment } \\
\text { and Modeling - IAM }\end{array}$ & $\begin{array}{c}\text { Strategic/Operational } \\
\text { (plans, programs, projects) }\end{array}$ & Ex-Ante & No \\
\hline $\begin{array}{l}\text { Research Impact } \\
\text { Assessment - RIA }\end{array}$ & $\begin{array}{c}\text { Operational } \\
\text { (projects, technologies, } \\
\text { products, services) }\end{array}$ & Ex-Post & No \\
\hline $\begin{array}{l}\text { Life Cycle Sustainability } \\
\text { Assessment - LCSA }\end{array}$ & $\begin{array}{c}\text { Operational } \\
\text { (projects, activities) }\end{array}$ & Ex-Ante & No \\
\hline $\begin{array}{l}\text { Impact Analysis of the } \\
\text { Public Agronomic } \\
\text { Research - ASIRPA }\end{array}$ & $\begin{array}{c}\text { Operational } \\
\text { (projects, technologies) }\end{array}$ & Ex-Post & No \\
\hline $\begin{array}{l}\text { IMPact of RESearch in } \\
\text { the South -IMPRESS }\end{array}$ & $\begin{array}{c}\text { Operational } \\
\text { (projects, technologies) }\end{array}$ & Ex-Post & No \\
\hline $\begin{array}{l}\text { Social Report / } \\
\text { Ambitec-Agro } \\
\text { (Integrated Impact } \\
\text { Assessment) } \\
\end{array}$ & $\begin{array}{c}\text { Strategic/Operational } \\
\text { (projects, technologies, } \\
\text { products, services) }\end{array}$ & Ex-Post & Partially \\
\hline $\begin{array}{l}\text { Sustainability Report } \\
\text { (SR) }\end{array}$ & $\begin{array}{c}\text { Strategic/Operational } \\
\text { (plans, programs, projects, } \\
\text { general actions and } \\
\text { activities) }\end{array}$ & Ex-Post & No \\
\hline
\end{tabular}




\section{Macrothink \\ Environmental Management and Sustainable Development \\ ISSN 2164-7682 \\ 2017, Vol. 6, No. 2}

\section{Conclusion and Suggestion for Future Researches}

Organizations implement policies, plans, programs, projects and activities, and generate products and services. Then, organizations generate impacts and conflicts of interest. All these conflicts and impacts can be well governed and managed if organizations create consistent systems of impact assessment. As a consequence, organizations that are more sustainable in their processes, products and services will propitiate a more sustainable world. Organizations can help their personnel to construct more sustainable attitudes that can be disseminated to their families, friends and others. The complexity of the theme and the interweaving of social, environmental and economic components require an essentially holistic and transdisciplinary vision, demanding more extensive creation for integrative methodologies on impact assessment under sustainability perspective and using a transversal cut for analysis. Few methodologies and experiences have demonstrating balance among all dimensions, and, in general, have been adopting methods or practices with bias by emphasizing one aspect in prejudice of another one.

Below, Figure 2, can demonstrate how a transversal perspective set each dimension into its appropriate scale inasmuch as: economic environment is part of society which is structured by organizations and experts who integrate the social environment; society is inserted into the local, national and international space which is into the planet; thus, the planet and the environment represent the biggest space or ambience where society and the economy are, respectively, inset. It is a basic mathematic question: the smallest universe is within the larger one. This interrelationship does not means that one is more important than another, but despite equal ponderosity it is concrete that if environment is not protected, the society will suffer consequences and the economic environment will be deteriorated. The economic system to survive has to create sustainable instruments and mechanisms for society to support itself with quality of life on an equitable social structure, as well as, to provide quality of life today and for future society it has to conserve environment in resilient balance.

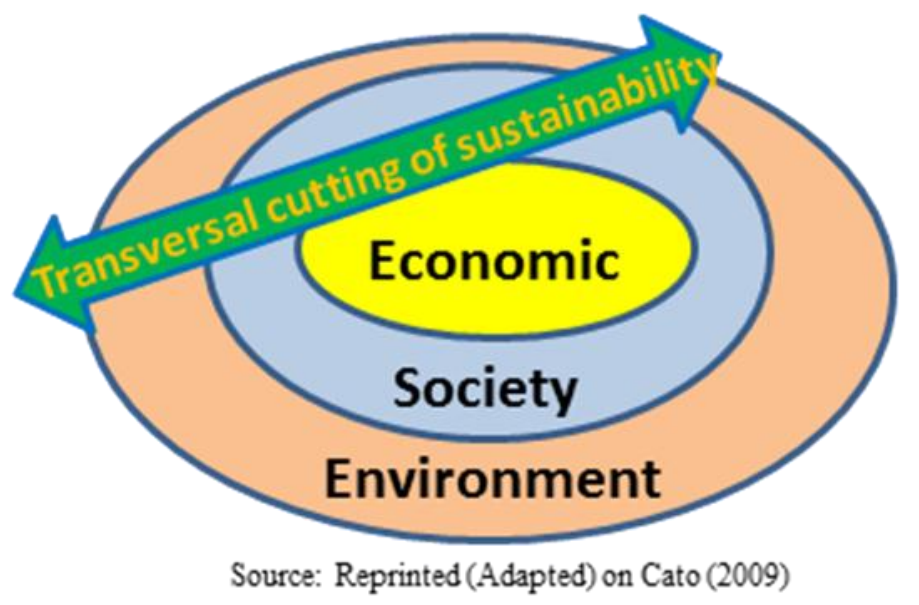

Figure 2. Integrated and transversal view for sustainability

Suitable methodologies need to be constructed through an integrated, transversal, holistic and transdisciplinary perspective, using high participatory stakeholder process (including 
consumers, as last stage of chain). Ethical attitudes for data and information collecting and for report elaboration are needed, while demonstrating positive and negative, realities, displaying transparence for society from their products, processes and service impacts. Presently, assessment approaches are fragmented by ex-ante or ex-post analysis, focusing emphatically environmental, social or economic dimensions. For the future, a new methodology could be based on a general model that could stimulate balance among all dimensions. This new perspective implies the review of the concept of impact assessment by a complete process, including ex-ante and ex-post as part of a whole managerial assessment system. Surely, balanced reports can be much more useful for strategic, tactical and operational decision-making processes, adjusting plans, improving programs, processes, projects, products and services toward a more sustainable production.

Thus, we recommend for next researches: 1. a deeper comparative analysis on sustainability impact assessment among agricultural research organizations by a holistic, transdisciplinary and transversal perspective; 2. propose improvement to existed impact assessment approaches, including proposition of sustainability impact assessment model for technological agricultural innovations by combining several methodologies such as SR based on GRI, Integrated Impact Assessment TBL according to Embrapa, CIRAD and other institution's experiences. Transition Management and Sustainability Transition could be timely approached to base a governance-managerial platform for supporting the proposed model and future system of sustainability impact assessment of agricultural research organizations; 3. to test and validate (in field) the proposed governance-managerial model for sustainability impact assessment of agricultural technological solutions.

\section{Acknowledgement}

The research is financed by IRD and Embrapa. I am grateful for Prof. Helen Gurgel, University of Brasilia.

\section{References}

Alston, J. M., Norton, G. W., \& Pardy, P. G. (1995). Science Under Scarcity: Principles and Practices for Agricultural Research Evaluation and Priority Setting (1st ed.). Cornell University Press and ISNAR, Ithaca, New York, USA, 105-107, 493

Asif, M., Searcy, C., Zutshi, A., \& Ahmad, N. (2011). An integrated management systems approach to corporate sustainability. European Business Review, 23(4), 353-367.

https://doi.org/10.1108/09555341111145744

Bantilan, Cynthia, Templeton, Debbie \& Craswell, Eric. (2014). Concepts and Tools for Agricultural Research Evaluation and Impact Assessment - Report on Master Class on Impact Assessment International. Edited by Crops Research Institute for the Semi-Arid Tropics,

Patancheru, A. P. (2009). India 18-27 March, Available:

https://www.crawfordfund.org/wp-content/uploads/2014/03/Impact_assesment_Masterclass.p df.

Barret, D., Clavel, D., Dabat, M-H., Faure, G., Mathé, S., Temple, L., Toillier, A., \& 
Triomphe, B. (2015). Impress - Guide méthodologique sur l'évaluation des impacts de la recherche agronomique dédiée aux pays du sud. Centre de coopération internationale en recherche agronomique pour le développemen-Cirad. Available:

http://impress-impact-recherche.cirad.fr/

Becker, Henk A. (2001). Social impact assessment. European Journal of Operational Research, 128, 311-321. https://doi.org/10.1016/S0377-2217(00)00074-6

Becker, Henk A., \& Vanclay, Frank. (2003).The International Handbook of Social Impact Assessment: conceptual and methodological advances. ISBN-10: 1840649356, Edward Elgar Publishing Limited, illustrated edition, 4-12, 129-142.

https://doi.org/10.4337/9781843768616

Bond, Alan, J., \& Morrison-Saunders, Angus. (2011). Re-evaluating Sustainability Assessment: Aligning the vision and the practice. Environmental Impact Assessment Review, 31, 1-7. https://doi.org/10.1016/j.eiar.2010.01.007

Cato, Molly Scott. (2009). Green Economics: An Introduction to Theory, Policy and Practice, pp. 37. First published by Earthscan. London, UK. Available:

http://www.gci.org.uk/Documents/128075741-Green-Economics-an-Introduction-to-TheoryPolicy-and-Practice.pdf

Convention on Biological Diversity - CBD. (2006). The voluntary guidelines for biodiversity-inclusive impact assessment, adopted through decision VIII/28. Available: https://www.cbd.int/doc/publications/imp-bio-eia-and-sea.pdf

CGIAR, About Us. (2017). Official Site. Available: www.cgiar.org

Chesbrough, H. W., West, J., \& Vanhaverbeke, W. (2006). Open Innovation: Researching a New Paradigm, pp. 21-94, ISBN: 9780199226467. Oxford: Oxford University Press, Oxford, UK

Chowdhury, Dhiman Deb. (2013). Organizational Citizenship Behavior Towards Sustainability. International Journal of Management, Economics and Social Sciences, 2(1), 28-53.

Cohen, E., \& Lloyd, S. (2014). Disciplinary evolution and the rise of the transdiscipline. Informing Science: the International Journal of an Emerging Transdiscipline, 17,189-215. Online ISSN: 1521-4672, Print ISSN: 1547-9684. Available:

https://www.informingscience.org/Publications/2045?Search=Transdiscipline

Colinet, Laurence ; Joly, Pierre Benoit ; Gaunand, Ariane ; Matt, Mireille ; Laredo, Philippe, et al.. (2014). ASIRPA - Analyse des Impacts de la Recherche Publique Agronomique. Rapport final.[Rapport de recherche] Institut National de la Recherche Agronomique. 2014, 61 p.<hal-01190008>. Available : https://hal.archives-ouvertes.fr/hal-01190008/document

Christensen, Clayton, M., Raynor, Michael, E., \& McDonald, Rory. (2015). What is disruptive innovation? Harvard Business Review, December, 2015. Available: https://hbr.org/2015/12/what-is-disruptive-innovation 
Delmottea, Sylvestre, Lopez-Ridauraa, Santiago, Barbiera, Jean-Marc, Weryb, Jacques. (2013). Prospective and participatory integrated assessment of agricultural systems from farm to regional scales: Comparison of three modeling approaches. Journal of Environmental Management, 129, 493-502. https://doi.org/10.1016/j.jenvman.2013.08.001

De Smedt, Peter. (2010). The use of impact assessment tools to support sustainable policy objectives in Europe. Ecology and Society, 15(4), 30.

https://doi.org/10.5751/es-03623-150430

Douthwaitea, Boru, Kubyb, Thomas, Fliertc, Elske van de \& Schulzd, Steffen. (2003). Impact pathway evaluation: an approach for achieving and attributing impact in complex systems. Agricultural Systems, 78, 243-265. https://doi.org/10.1016/S0308-521X(03)00128-8

Eccleston, Charles H. (2011). Environmental Impact Assessment: A Guide to Best Professional Practices. CRC Press Taylor \& Francis Group. https://doi.org/10.1201/b10717

Empresa Brasileira de Pesquisa Agropecuaria - Embrapa. (2017). Gestão Estratégica -Embrapa gera impactos efetivos para a sociedade brasileira. Available: https://www.embrapa.br/group/intranet/busca-de-noticias/-/noticia/21885057/embrapa-gera-i mpactos-efetivos-para-a-sociedade-brasileira

ERCHP - European Centre for Health Policy. (1999). Gothenburg Consensus Paper - Health Impact Assessment: main concepts and suggested approach. World Health Organization WHO Regional Office for Europe, 1999. Available:

http://www.impactsante.ch/pdf/HIA_Gothenburg_consensus_paper_1999

European Environmental Agency (EEA) (2001). Participatory Integrated Assessment methods: an assessment of their usefulness for the European Environmental Agency. Technical Report 64, Copenhagen. Available:

http://www.pedz.uni-mannheim.de/daten/edz-bn/eua/01/tech64.pdf

Ewert, F., Rötter, R. P., Bindi, Webber, M., Trnka, H.,M., Kersebaum, K. C., ... Bartošová, L. (2015). Crop modelling for integrated assessment of risk to food production from climate change. Environmental Modelling \& Software. Elsevier, 72, 287-303.

https://doi.org/10.1016/j.envsoft.2014.12.003

FAO - Food and Agricultural. (2012). Environmental Impact Assessment (EIA): Guidelines for FAO Field Projects, ISBN 978-92-5-107276-9: http://www.fao.org/3/a-i2802e.pdf

-------. (2015). International Fund for Agricultural Development - IFAD; World Food Programme - WFP. Achieving Zero Hunger The critical role of investments in social protection and agriculture: http://www.fao.org/3/a-i4777e.pdf

Freeman, Joshua. (2005). Towards a definition of holism. British Journal of General Practice - Br. J. Gen Pract, 55 (511), 154-155. Available:

https://www.ncbi.nlm.nih.gov/pmc/articles/PMC1463203/

Freudenburg, William R. Social Impact Assessment. (1986). Annual Review of Sociology, 12, 451-478. https://doi.org/10.1146/annurev.so.12.080186.002315 
Gatherer, Derek. (2010). So what do we really mean we say that systems biology is holistic? BMC Systems Biology, 4, 22. Available:

https://bmcsystbiol.biomedcentral.com/articles/10.1186/1752-0509-4-22

Global Report Initiative - GRI. (2017). Website, Empowering Sustainable Decisions. Available:

https://www.globalreporting.org/information/sustainability-reporting/Pages/default.aspx

------. (2010). GRI Reporting in Government Agencies. GRI ISBN number: 978-90-8866-033-7. Available: https:/www.globalreporting.org/Pages/default.aspx

Gray, Barbara. (2008). Enhancing Transdisciplinary Research through Collaborative Leadership. US National Library of Medicine - National Institutes of Health - Am J Prev Med. 35(2 Suppl): S124-S132. https://doi.org/10.1016/j.amepre.2008.03.037

Hadorn, Gertrude Hirsch, \& Pohl, Christian. (2007).Principles for Designing Transdisciplinary Research. ISBN-13: 978-3-86581-046-5, Oekon 1st Edition, p. 3-42 Munich (Germany).

Harris, G. (2002). Integrated assessment and modeling - science for sustainability. R. Costanza, S. E. Joergensen (Eds.), Understanding and Solving Environmental Problems in the 21st Century, Elsevier, 5-17. https://doi.org/10.1016/b978-008044111-5/50003-2

Impact Assessment Institute - IAI / The Institute for Impact Assessment and Scientific Evaluation of Policy and Legislation. (2017). IAI Website, About the Impact Assessment Institute, definition specified at the second paragraph. Available: http://www.impactassessmentinstitute.org/about

INRA - Science \& Impact and CIRAD. (2016). Comité consultatif commun d'éthique pour la recherche agronomique. Avis 9 sur les enjeux éthiques de l'évaluation des impacts de la recherche publique agronomique. Available:

https://inra-dam-front-resources-cdn.brainsonic.com/ressources/afile/347600-2f44f-resourceavis-9-du-comite-d-ethique.pdf

International School on Research Impact Assessment - ISRIA. (2017). Available: http://theinternationalschoolonria.com/

ISO - International Organization for Standardization. (2015). Introduction to ISO 14001Available:

https://www.iso.org/files/live/sites/isoorg/files/archive/pdf/en/introduction_to_iso_14001.pdf

Joly, P. et al. (2016). Agricultural research impact assessment: Issues, methods and challenges, OECD Food, Agriculture and Fisheries Papers, https://doi.org/10.1787/5339e165-en

Kuby, T. (1999). Innovation as a Social Process: What Does this Mean for Impact Assessment in Agricultural Research. Paper presented at a CIAT workshop, Costa Rica, September 1999.

Loorbach, Derk, \& Rotmans, Jan. (2010). The practice of transition management: Examples and lessons from four distinct cases. Futures, 42, 237-246. 
https://doi.org/10.1016/j.futures.2009.11.009

Markard, Jochen, Raven, Rob, \& Truffer, Bernhard. (2012). Sustainability transitions: An emerging field of research and its prospects. Research Policy, 41(6), 955-967. https://doi.org/10.1016/j.respol.2012.02.013

MasterQResearch. (2012). Socio-Economic Impact Assessment as part of the Environmental Impact Assessment Process for the Proposed Thyspunt Lines Integration Project DWEA Ref. No. 12/12/20/1212: Northern Corridor - The construction and operation of 3x 400kV transmission power lines: 1x Thyspunt Grassridge and 2x Thyspunt - Dedisa, South Africa, Dec 2010. Available:

http://www.eskom.co.za/OurCompany/SustainableDevelopment/EnvironmentalImpactAssess ments/Documents/EIA_SIA_Report_NC_Rev_1.pdf

Merrey, D. J. (2015). An Evaluation of CGIAR Centers' Impact Assessment Work on Irrigation and Water Management Research. Rome, Italy, Standing Panel on Impact Assessment (SPIA), CGIAR Independent Science and Partnership Council (ISPC). 83 pp. Available: http://impact.cgiar.org/evaluation-cgiar-centers-impact-0

Mitrany, Michal, \& Stokols, Daniel. (2005). Gauging the Transdisciplinary Qualities and Outcomes of Doctoral Training Programs. Journal of Planning Education and Research, 24, 437-449. https://doi.org/10.1177/0739456X04270368

Morin, Edgar. (1990). Science avec conscience, Paris: Edition Seuil, pp 36-38.

et Le Moigne, Jean-Louis. (2003). L'intelligence de la complexité. Ed. L'Harmallan, France. EAN13: 9782738480859.

National Institute of Statistics and Economics Studies of France - INSEE. (2016). Available: https://www.insee.fr/en/metadonnees/definition/c1182

NCVO - The National Council for Voluntary Organisations, England. (2017). Written by Dr Richard Piper. Available :

https://knowhownonprofit.org/organisation/impact/about-impact-and-evaluation/understandin g-the-language. Published in 02/2017

Nidumolu, Ram, Prahalad, C. K., \& Rangaswami, M. R. (2009). Why Sustainability Is Now the Key Driver of Innovation. Harvard Business Review, September 2009: Available: https://hbr.org/2009/09/why-sustainability-is-now-the-key-driver-of-innovation

Organisation for Economic Co-Operation and Development - OECD. (2010). Guidance on Sustainability Impact Assessment. 2010 edition. Available:

http://www.oecd.org/greengrowth/48305527.pdf

O'Sullivan, D. (2009). Applying Innovation. Sage Publishing, Thousand Oaks $1^{\text {st }}$ Ed., California, pp 3.

Oxford Economics. (2013).The economic impact of Starbucks on the UK economy. A report for Starbucks. Available: http://www.oxfordeconomics.com/my-oxford/projects/278163 
(2015).The impact of BAE systems on the UK economy. Available: http://www.oxfordeconomics.com/my-oxford/projects/311905

Piaget, Jean. (1972). Epistemologie des relations interdisciplinaires. In: CERI (EDS.) L'interdisciplinarité. Problèmes d'enseignement et de recherche dans les Universités, p. 131144. Paris: UNESCO/OCDE.

Pisano, Umberto; Lange, Lisa, \& Berger, Gerald. (2015). Social Innovation in Europe An overview of the concept of social innovation in the context of European initiatives and practices. ESDN Quarterly Report.

Planing, Patrick. (2017). On the origin of innovations-the opportunity vacuum as a conceptual model for the explanation of innovation. Journal of Innovation and Entrepreneurship, 6, 5. https://doi.org/10.1186/s13731-017-0063-2

Popa, Florin; Guillermin, Mathieu, \& Dedeurwaerdere, Tom. (2015). A pragmatist approach to transdisciplinarity in sustainability research: From complex systems theory to reflexive science. Futures, 65, 45-56, https://doi.org/10.1016/j.futures.2014.02.002

Pope, Jenny; Annandale, David and Morrison-Saunders, Angus. (2004). Conceptualising sustainability assessment. Environmental Impact Assessment Review, 24, 595-616.

https://doi.org/10.1016/j.eiar.2004.03.001

Rodrigues, Geraldo Stachetti, Buschinelli, Cláudio and Avila, Antonio Flavio. (2010). An Environmental Impact Assessment System for Agricultural Research and Development II: Institutional Learning Experience at Embrapa. Journal of Technology Management \& Innovation J. Technol. Manag. Innov., 5(4), 38-56.

https://doi.org/10.4067/S0718-27242010000400004

Rodrigues, Geraldo Stachetti.(2015). Avaliaçao de Impactos Socioambientais de Tecnologias na Embrapa. Publication Embrapa Documentos, 99.

Roquete, Fátima; Amorim, Maria, Barbosa, Simone, Souza, Danielle, Carvalho, Vilma. R. Enferm. (2012). Dialogue among knowledge: multidisciplinarity, interdisciplinarity and transdisciplinarity in public health field. Cent. O. Min. set/dec, 2(2), 463-474.

Ruegg, R. \& Feller, I. (2003). A Toolkit for Evaluating Public R\&D Investment: Models, Methods, and Findings from ATP's First Decade., Gaithersburg: National Institute of Standards and Technology.

Sadler, Barry and Dalal-Clayton, Barry. (1999). Strategic Environmental Assessment: A Rapidly Evolving Approach, ISBN: 190403533 7.IIED, London. Available:

http://pubs.iied.org/pdfs/7790IIED.pdf

Scholz, R.W.; Mieg, H.A.; Oswald, J.E. (2000). Transdisciplinarity in groundwater management - Towards mutual learning of science and society. Water, Air, \& Soil Pollution, 123(1-4), 477-487. https://doi.org/10.1023/A:1005292328778

SCHUMPETER, J. A. The theory of economic development. (1983). Transaction Publishers, 


\section{Al Macrothink}

Environmental Management and Sustainable Development

ISSN 2164-7682

2017, Vol. 6, No. 2

New Brunswick, New Jersey, USA, pp. 112-160. Original material copyright 1934 by the President and Fellows of Harvard College. ISBN: 978-0-87855-698-4.

The Review Board. (2007). Socio-Economic Impact Assessment Guidelines. Mackenzie Valley Environmental Impact Review Board: Available:

http://www.reviewboard.ca/upload/ref_library/SEIA_Guidelines_Contents_and_Chapter_1.p df

UN - United Nations. (1987). Our Common Future Report, March 1987. Available: http://www.un-documents.net/our-common-future.pdf

(1992). Agenda 21, Item 8.3 - Sustainable Development. United Nations Conference on Environment \& Development Rio de Janerio, Brazil, 3 to 14 June 1992. Available: https://sustainabledevelopment.un.org/content/documents/Agenda21.pdf

(2012). Realizing the Future We Want for All, Report the Secretary-General, (A/CONF.216/1.1) New York, paragraph 252. For the complete report, please check: Available:

http://www.un.org/en/development/desa/policy/untaskteam_undf/report.shtml

-------.(2015). Transforming our world: the 2030 Agenda for Sustainable Development. General Assembly. Resolution adopted by the General Assembly on 25 September 2015 (seventieth session), http://www.un.org/ga/search/view_doc.asp?symbol=A/RES/70/1\&Lang=E

United Nations Environment Programme - UNEP. (2004). Environmental Impact Assessment and Strategic Environmental Assessment: Towards an Integrated Approach. Edited and published by UNEP, Geneva. Available: http://unep.ch/etu/publications/textONUBr.pdf

/SETAC. (2011).Towards a life cycle sustainability assessment: Making informed choices on products. Life Cycle Initiative. ISBN: 978-92-807-3175-0, Job Number: DTI/1412/PA.

Available: http://www.unep.fr/shared/publications/pdf/DTIx1412xPA-Towards\%20a\%20LCSAMakingI nformedChoice.pdf

Verheem, R. (2002). Recommendations for Sustainability Assessment in the Netherlands. In Commission for EIA. Environmental Impact Assessment in the Netherlands. Views from the Commission for EIA in 2002. The Netherlands. Available:

https://www.researchgate.net/publication/267399927_Experiences_on_Sustainability_Assess ment_in_the_Netherlands

Wernham, Aaron. (2011). Health Impact Assessments Are Needed In Decision Making About Environmental And Land-Use Policy. Health Aff, 30, 5947-956.

https://doi.org/10.1377/hlthaff.2011.0050

Yang, Zili, Wei, Yi-Ming, \& Mi, Zhifu. (2016). Integrated Assessment Models (IAMs) for Climate Change. Oxford Bibliographies Online. LAST MODIFIED, 28.

https://doi.org/10.1093/obo/9780199363445-0043 


\section{Macrothink \\ Environmental Management and Sustainable Development \\ ISSN 2164-7682 \\ 2017, Vol. 6, No. 2}

\section{Copyright Disclaimer}

Copyright for this article is retained by the author(s), with first publication rights granted to the journal.

This is an open-access article distributed under the terms and conditions of the Creative Commons Attribution license (http://creativecommons.org/licenses/by/3.0/). 